Економічні науки: збірник наукових прачь Луцького національного технічного університету. - Серія "Регіональна економіка". - Випуск 16 (63). - Редкол.: відп. ред. д.е.н., професор Л.Л. Ковальська - Луиьк: ІВВ Луиького НТУ, 2019. - 173 с.

УДК 353.2:338.49

Кривов’язюк I.В., к.е.н., профессор

Луцький національний технічний університет

\title{
НАРОЩЕННЯ ПІДПРИЄМНИЦЬКОГО ПОТЕНЦІАЛУ РЕГІОНУ ЯК РЕЗУЛЬТАТ СТВОРЕННЯ РЕГІОНАЛЬНИХ СТУДІЙ ПІДПРИЄМНИЦЬКОЇ МАЙСТЕРНОСТІ
}

В даній статті вирішено складне наукове завдання - розвиток прикладних засад нарощення підприємницького потенціалу регіону. 3'ясовано, що мета створення регіональних студій підприємницької майстерності тісно переплітається з сутністю та змістом підприємницького потенціалу регіону. Визначено, що наявне використання підприємницького потенціалу в регіонах України значно гірше, ніж у країнах ЄС. Запропоновано механізм забезпечення нарощення підприємницького потенціалу регіону як результат створення регіональних студій підприємницької майстерності.

Ключові слова: підприємницький потенціал, інфраструктура регіону, студії підприємницької майстерності, інноваційність, регіон. 

університету. - Серія "Регіональна економіка". - Випуск 16 (63). - Редкол.: відп. ред. д.е.н., професор Л.Л. Ковальська - Луцьк : ІВВ Луцького НТУ, 2019. -173 с.

Kryvovyazyuk I.V.

\section{CUMULATUON OF THE ENTREPRENEURIAL POTENTIAL OF THE REGION AS A RESULT OF THE CREATION OF REGIONAL ENTREPRENEURIAL SKILLS STUDIOS}

In this article a complex scientific problem - the development of applied foundations for increasing the entrepreneurial potential of the region is solved.

Increasing the entrepreneurial potential of a region is one of the most important factors for its economic growth. This is ensured by the action of both extensive (increasing the number of business structures and their property support, increasing jobs, developing infrastructure, etc.), and intensive factors (improving productivity, creating a positive image of the entrepreneur, stimulating innovation, etc.). Establishment of regional studies of entrepreneurial skills as infrastructure entities, which activity creates the necessary conditions for the formation of opportunities for growth of entrepreneurial skills in a certain region is aimed to increase the efficiency of the realization of entrepreneurial potential by all economic entities of each region of the state and the country at all.

By means of a critical analysis of scientific publications of scientists on the problems of entrepreneurship development in the context of the investigated problems, two directions of research are distinguished: the sphere of research, devoted to the issues of formation and development of entrepreneurial potential of the region, and the sphere of research, which reveal the theoretical-methodological and applied principles of creating regional studios of entrepreneurship. It is necessary to disclose the relationship between these two directions.

It has been found out that the purpose of creation of regional studies of entrepreneurial skills, which consists in forming a platform for acquiring business skills, business planning, studying the methodology of evaluating the effectiveness of implementation of business projects, mastery of entrepreneurial skills, development of startups is closely intertwined with the essence and content of entrepreneurial potential of the region as an ability of the regional system of entrepreneurship on an innovative basis to solve the problems of socio-economic development of the region on the basis of combining different types of potentials, and the existing use of entrepreneurial potential in the regions of Ukraine is much worse than in the EU countries.

To solve the problem, the mechanism of providing the business potential of the region is suggested as a result of the creation of regional studies of entrepreneurial skills, the interaction of its components such as organizational, financial-investment, information and scientific-technical, provide solutions to the problems of socio-economic development of the region.

The implementation of such a mechanism to ensure the growth of entrepreneurial potential of the region will allow to increase the number of small and 
Економічні науки: збірник наукових праць Луцького національного технічного університету. - Серія "Регіональна економіка". - Випуск 16 (63). - Редкол.: відп. ред. д.е.н., професор Л.Л. Ковальська - Луцьк : ІВВ Луцького НТУ, 2019. -173 с.

medium-sized business entities in the region, to develop the entrepreneurial infrastructure, to increase the innovation activity of small and medium-sized business entities in the region.

Further research will focus on finding reserves for improving the efficiency of regional governance through the introduction of a mechanism to ensure the entrepreneurial capacity of the region as a result of the creation of regional studies of entrepreneurial skills.

Key words: entrepreneurial potential, infrastructure of the region, entrepreneurial skills studios, innovation, region.

Кривовязюк И.В.

\section{НАРАЩИВАНИЕ ПРЕДПРИНИМАТЕЛЬСКОГО ПОТЕНЦИАЛА РЕГИОНА КАК РЕЗУЛЬТАТ СОЗДАНИЯ РЕГИОНАЛЬНЫХ СТУДИЙ ПРЕДПРИНИМАТЕЛЬСКОГО МАСТЕРСТВА}

В данной статье решена сложная научная задача - развитие прикладных основ наращивания предпринимательского потенциала региона. Выяснено, что цель создания региональных исследований предпринимательского мастерства тесно переплетается с сущностью и содержанием предпринимательского потенциала региона. Определено, что существующее использование предпринимательского потенциала в регионах Украины значительно хуже, чем в странах ЕС. Предложен механизм обеспечения наращивания предпринимательского потенциала региона как результат создания региональных студий предпринимательского мастерства.

Ключевые слова: предпринимательский потенциал, инфраструктура региона, студии предпринимательского мастерства, инновационность, регион.

Постановка проблеми у загальному вигляді та їі зв'язок 3 важливими науковими й практичними завданнями. Нарощення підприємницького потенціалу регіону $\epsilon$ одним iз найважливіших чинників його економічного зростання. Це забезпечується завдяки дії як екстенсивних (збільшення кількості підприємницьких структур і їх майнова підтримка, збільшення робочих місць, розвиток інфраструктури тощо), так і інтенсивних факторів (підвищення продуктивності праці, створення позитивного іміджу підприємця, стимулювання інноваційної активності тощо). Створення регіональних студій підприємницької майстерності як інфраструктурних утворень, діяльність яких створює необхідні умови формування 
Економічні науки: збірник наукових праџь Луцького національного технічного університету. - Серія "Регіональна економіка". - Випуск 16 (63). - Редкол.: відп. ред. д.е.н., професор Л.Л. Ковальська - Луцьк: ІВВ Луцького НТУ, 2019. - 173 с.

можливостей зростання підприємницької майстерності у визначеному регіоні, i покликане підвищити ефективність реалізації підприємницького потенціалу усіма суб'єктами господарювання кожного регіону держави та країни в цілому.

Дослідження виконано в рамках держбюджетної тематики «Механізми створення регіональних студій підприємницької майстерності в умовах децентралізації економіки» (№ 222-17).

Аналіз останніх досліджень і публікацій. Вивчення змісту наукових праць вчених сучасності у сфері розвитку підприємництва показало, що їх слід розділити на дві групи. Перша представлена результатами досліджень, що стосуються процесів формування та розвитку підприємницького потенціалу: в роботі А. Чайкіної [16] розкрито теоретичні засади формування поняття «підприємницький потенціал регіону»; наукові напрацювання М. Забедюк [1], Л. Ковальської та К. Оксенюк $[2 ; 13]$, визначають сутність, зміст, структуру та напрями забезпечення розвитку підприємницького потенціалу регіону; форми розвитку інноваційної підприємницької діяльності визначено в роботі [14], а методичний підхід до аналізу та оцінки розвитку інноваційного підприємництва регіонів України в дослідженні [4]; I. Пушкарчук та О. Мишко [15] зосереджують увагу на особливостях розвитку та ролі підприємництва різних сфер виробництва в економіці України; на існуючих трансформаціях в підприємництві та зростанні ролі лідерства акцентується увага в доробку [17]; проблемам розвитку підприємництва в регіонах приділено увагу в дослідженнях Н. Кухарук $[9 ; 10 ; 12]$. Друга група наукових публікацій присвячена дослідженню теоретико-методичних і прикладних засад створення регіональних студій підприємницької майстерності в умовах децентралізації економіки і знайшла розкриття в роботах $[3 ; 4 ; 6-8 ; 11]$. Однак, в напрацюваннях науковців практично не приділено уваги взаємозв'язку цих двох напрямків, а саме залежності нарощення підприємницького потенціалу регіону від створення регіональних студій підприємницької майстерності. 
Економічні науки: збірник наукових праџь Луцького національного технічного університету. - Серія "Регіональна економіка". - Випуск 16 (63). - Редкол.: відп. ред. д.е.н., професор Л.Л. Ковальська - Луцьк: ІВВ Луиького НТУ, 2019. - 173 с.

Цілі статті. Метою дослідження є розвиток прикладних засад нарощення підприємницького потенціалу регіону.

Виклад основного матеріалу. Як стверджує Л. Ковальська, «основна мета створення регіональних студій підприємницької майстерності полягає у формуванні платформи 3 вивчення (набуття) бізнес-навиків, бізнес-планування, методики оцінки ефективності реалізації бізнес-проектів, оволодінні підприємницькою майстерністю, розробці стартапів тощо як цілісної та відкритої системи зі створення прозорих умов ведення підприємницької діяльності. Така студія стане передумовою до формування інвестиційного середовища, ринку інвестицій, конкретних інвестиційних пропозицій 3 боку інвесторів, які бажають інвестувати у конкретні бізнес-ідеї» [5, с. 108-109].

Даний підхід цілком відповідає сутності підприємницького потенціалу регіону як «здатності регіональної системи підприємництва на інноваційній основі вирішувати завдання економічного та соціального розвитку цієї території, формуючи унікальні комбінації ресурсного, науковотехнічного, інформаційного та інших потенціалів [16].

Переважна більшість українських компаній в секторі підприємництва - це малі та середні підприємства, подібно до більшості країн по всьому світі. У 2017 році підприємства 3 кількістю найманих працівників менше 250 осіб становили понад 99\% всіх підприємств в економіці підприємництва, на їх долю припадало 61\% загальної зайнятості в підприємництві, 54\% загального обсягу реалізованої продукції та 47\% створеної у підприємництві доданої вартості. 89\% усіх підприємств працюють у секторі послуг, і на них припадає майже 45\% зайнятості, а також вони генерують 56\% доданої вартості. Майже половина доданої вартості послуг бізнесу створена у секторі оптової та роздрібної торгівлі. У 2017 році 14\% підприємств всієї економіки були розташовані у столиці - Києві, і на них було зайнято $24 \%$ робочої сили. Крім цього, у Києві було зосереджено 11\% приватних підприємців та 25\% загальної кількості юридичних осіб. На останні припадало $30 \%$ робочої 
Економічні науки: збірник наукових праць Луцького національного технічного університету. - Серія "Регіональна економіка". - Випуск 16 (63). - Редкол.: відп. ред. д.е.н., професор Л.Л. Ковальська - Луцьк: ІВВ Луцького НТУ, 2019. - 173 с.

сили і 40\% обсягу реалізованої продукції усієї економіки України. Слід відмітити, що продуктивність праці на підприємствах малого та середнього підприємництва є значно нижчою, ніж на аналогічних суб'єктах господарювання Туреччини, Угорщини, Польщі, Словаччини, Чехії тощо. В регіональному розрізі, найбільша частка суб'єктів підприємництва України припадає на м. Київ і Київську область, а також Харківську, Дніпропетровську, Одеську, Львівську області, яка становить майже $50 \%$ від їх загальної кількості $[18$, с. $15,16,27,31]$. Загалом порівняльна статистика показників діяльності суб'єктів малого та середнього підприємництва України $є$ значно гіршої, ніж у країнах $€ C$, що і вимагає розробки заходів 3 нарощення підприємницького потенціалу регіонів.

Механізм забезпечення нарощення підприємницького потенціалу регіону як результат створення регіональних студій підприємницької майстерності зведено на рисунку 1.

Реалізація такого механізму забезпечення нарощення підприємницького потенціалу регіону дозволить підвищити кількість суб'єктів малого та середнього бізнесу в регіоні, розвинути підприємницьку інфраструктуру, підвищити інноваційну активність суб'єктів малого та середнього бізнесу в регіоні.

В свою чергу, ефективне використання та нарощення підприємницького потенціалу в регіоні забезпечується за таких умов: матеріально-технічної, інформаційної та фінансової підтримки сфери малого й середнього бізнесу; спрощення процедури оформлення дозвільних документів; відпрацювання простої й доступної схеми вирішення земельних питань; розвиток лізингу машин, обладнання та інших засобів виробництва, складування, реалізації продукції; вдосконалення системи оподаткування підприємницької діяльності; підвищення рівня безпеки підприємницької діяльності; надання інформаційної (навчання, консультування), грошової допомоги безробітним (безпроцентної позики тощо), які бажають зайнятись підприємницькою діяльністю; у кожному регіоні 
Економічні науки: збірник наукових прачь Луцького національного технічного університету. - Серія "Регіональна економіка". - Випуск 16 (63). - Редкол.: відп. ред. д.е.н., професор Л.Л. Ковальська - Луцьк : ІВВ Луцького НТУ, 2019. -173 с.

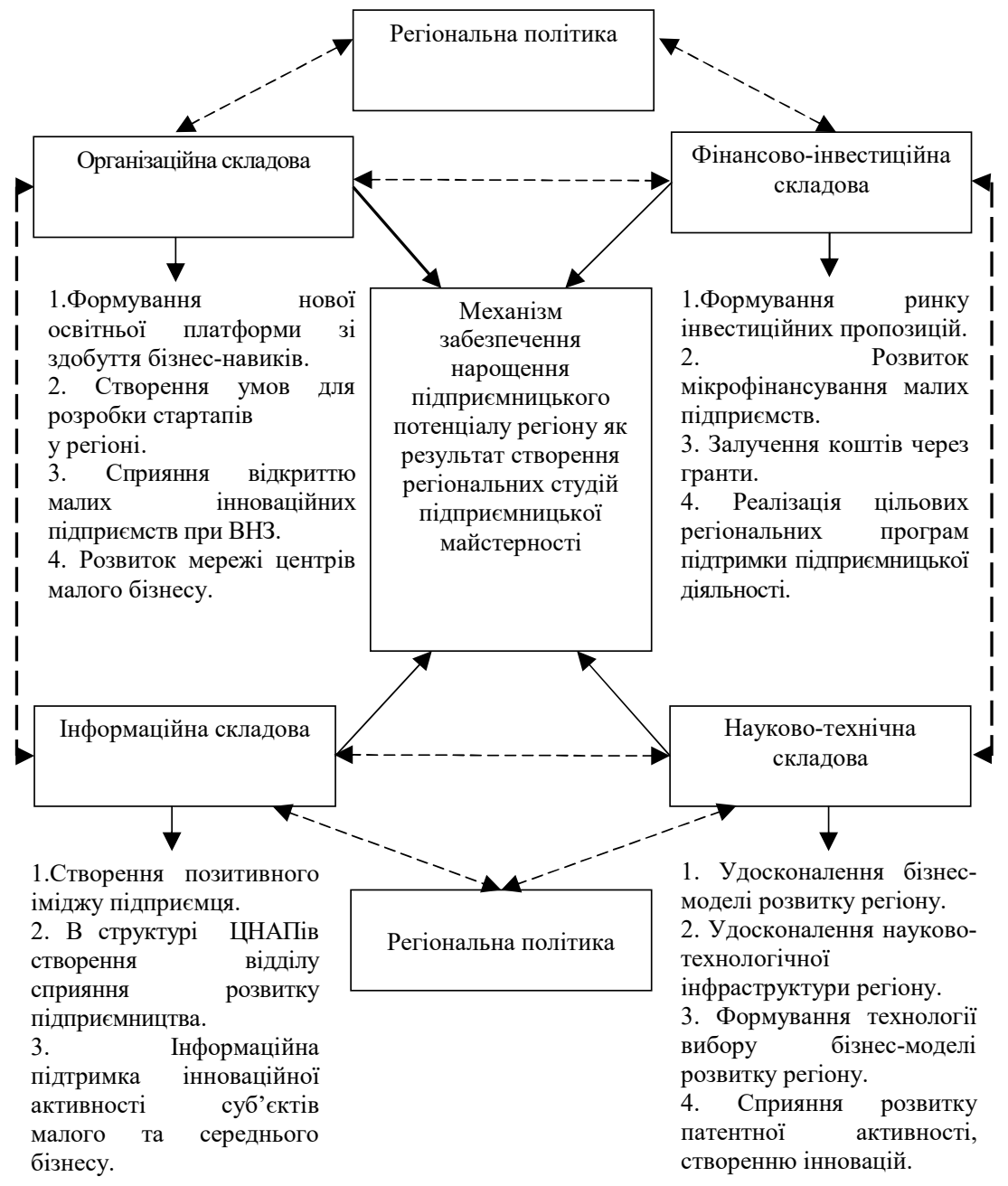

Рис. 2. Взаємодія складових механізму забезпечення нарощення підприємницького потенціалу регіону як результат створення регіональних студій підприємницької майстерності (авторська розробка) 
Економічні науки: збірник наукових праџь Луцького національного технічного університету. - Серія "Регіональна економіка". - Випуск 16 (63). - Редкол.: відп. ред. д.е.н., професор Л.Л. Ковальська - Луиьк: ІВВ Луиького НТУ, 2019. - 173 с.

доцільно створення бази даних, яка б містила інформацію про традиційні, специфічні для різних місцевостей ремесла з метою надання кваліфікованої інформаційної допомоги підприємцям, які бажають зайнятися таким видом діяльності [1, с. 187].

Висновки. В даній статті вирішено складне наукове завдання - розвиток прикладних засад нарощення підприємницького потенціалу регіону.

Шляхом критичного аналізу наукових публікацій вчених 3 проблем розвитку підприємництва в контексті досліджуваної проблематики виділено два напрямки досліджень: сфера досліджень, присвячена питанням формування та розвитку підприємницького потенціалу регіону та сфера досліджень, що розкривають теоретико-методичні та прикладні засади створення регіональних студій підприємницької майстерності. Визначено необхідність розкриття взаємозв'язку цих двох напрямів.

3'ясовано, що мета створення регіональних студій підприємницької майстерності тісно переплітається з сутністю та змістом підприємницького потенціалу регіону, а наявне використання підприємницького потенціалу в регіонах України значно гірше, ніж у країнах СC.

Для вирішення поставленого в роботі завдання запропоновано механізм забезпечення нарощення підприємницького потенціалу регіону як результат створення регіональних студій підприємницької майстерності, взаємодія таких його складових як організаційна, фінансово-інвестиційна, інформаційна та науково-технічна, забезпечують вирішення завдань соціально-економічного розвитку регіону.

Подальші дослідження буде спрямовано на пошук резервів підвищення ефективності регіонального управління на основі впровадження механізму забезпечення нарощування підприємницького потенціалу регіону як результату створення регіональних студій підприємницької майстерності. 
Економічні науки: збірник наукових праць Луцького національного технічного університету. - Серія "Регіональна економіка". - Випуск 16 (63). - Редкол.: відп. ред. д.е.н., професор Л.Л. Ковальська - Луцьк: ІВВ Луиького НТУ, 2019. - 173 с.

1. Забедюк М.С. Активізація підприємницького потенціалу як фактор розвитку бізнес середовища. Економічні науки. Сер.: Економіка та менеджмент. 2012. Вип. 9 (2). С. 183-188.

2. Ковальська Л.Л., Оксенюк К.І. Зміст та структура підприємницького потенціалу регіону. Економічний форум. 2019. № 2. С. 86-90.

3. Ковальська Л.Л. Інтелектуальний капітал як чинник розвитку підприємницької майстерності. Економічний форум. 2017. № 2. С. 101-106.

4. Ковальська Л.Л. Методичний підхід до аналізу та оцінки розвитку інноваційного підприємництва регіонів України. Сочіально-економічні проблеми сучасного періоду Украӥни. 2019. Вип. 2. С. 66-72.

5. Ковальська Л.Л. Механізм створення регіональних студій підприємницької майстерності в умовах децентралізації економіки. Економічні науки. Серія «Регіональна економіка». Збірник наукових праць. Луцький національний технічний університет. 2017. Випуск 14 (55). С. 106-112.

6. Кривов'язюк І.В. Концепт створення регіональних студій підприємницької майстерності. Молодий вчений. 2017. № 3(43). С. 698-701.

7. Кривов'язюк I.В. Механізм реалізації освітніх процесів в напрямку розвитку підприємницької майстерності. Економічний форум. 2017. №4. C. $135-141$.

8. Кривов'язюк I.В. Об'єктивні закономірності та теоретичні засади створення регіональних студій підприємницької майстерності в умовах децентралізації економіки. Ефективна економіка. 2017. №3. URL: http://www.economy.nayka.com.ua/?op=1\&z=5480.

9. Кривов'язюк І.В., Кухарук Н.В. Теоретичні засади розвитку підприємницького середовища в умовах децентралізації економіки. Економічний форум. 2017. № 3. С. 51-56.

10. Кривов'язюк І.В., Стрільчук Р.М., Кухарук Н.В. Підприємницька ініціатива в системі факторів розвитку інноваційної активності в регіоні. Економічні науки. Серія “Регіональна економіка”. Збірник наукових праць. Луцький національний технічний університет. 2018. Випуск 15 (59). C. $142-153$.

11. Кривов'язюк І.В., Хвищун Н.В., Кулик Ю.М. Діагностика потенціалу і розвиток підприємницької майстерності в регіоні. Економічні науки. Серія “Регіональна економіка”. Збірник наукових праць. Луцький національний технічний університет. 2017. Випуск 13 (51). С. 117-128.

12. Кухарук Н.В., Кривов’язюк I. В. Розвиток підприємництва в Україні та іiі регіонах. Східна Свропа: економіка, бізнес та управління. 2018. Випуск 3 (14). C. 82-87.

13. Оксенюк К.І. Підприємницький потенціал регіону: сутність та напрями забезпечення його розвитку. Економічний форум. № 3. 2017. С. 56-60.

14. Оксенюк К.І. Стартап як прогресивна форма розвитку інноваційної підприємницької діяльності. Молодий вчений. 2018. № 6 (1). С. 215-218.

15. Пушкарчук I.М., Мишко О.А. Особливості розвитку та роль підприємництва різних сфер виробництва в економіці України. Економічний 
Економічні науки: збірник наукових прачь Луцького національного технічного університету. - Серія "Регіональна економіка". - Випуск 16 (63). - Редкол.: відп. ред. д.е.н., професор Л.Л. Ковальська - Луцьк : ІВВ Луцького НТУ, 2019. -173 с.

форум. № 2. 2017. С. 41-48.

16. Чайкіна А.О. Теоретичні засади формування поняття «підприємницький потенціал». Вісник ОНУ. Серія: Економіка. 2014. Т. 19. Вип. 2/4. С. 231-235.

17. Igor Britchenko, Sergyi Smerichevskyi, Igor Kryvovyazyuk. Transformation of entrepreneurial leadership in the 21st century: prospects for the future. Advances in Social Science, Education and Humanities Research. Atlantis Press: Proceedings of the 2nd International Conference on Social, economic, and academic leadership (ICSEAL 2018), volume 217. pp. 115-121. DOI: $\frac{10.2991 / \text { icseal-18.2018.17. }}{18 . \text { OECD. } 361 \text {. }}$

18. OECD. Збірник статистики підприємництва в Україні: 2018. 42 с. URL: $\quad$ https://www.oecd.org/eurasia/competitiveness-programme/easternpartners/Compendium-Entreprise-Statistics-Ukraine-2018-Ukrainian.pdf (дата звернення: 18.11.2019). 